\title{
Influence of season and pollution on the antioxidant defenses of the cichlid fish acará (Geophagus brasiliensis)
}

\section{Wilhelm Filho ${ }^{1}$,}

M.A. Torres ${ }^{1}$, T.B. Tribess ${ }^{1}$,

R.C. Pedrosa ${ }^{2}$ and

C.H.L. Soares ${ }^{2}$

\author{
Departamentos de ${ }^{1}$ Ecologia e Zoologia and \\ Bioquímica, Centro de Ciências Biológicas, \\ Universidade Federal de Santa Catarina, \\ Florianópolis, SC, Brasil
}

\section{Correspondence \\ D. Wilhelm Filho \\ Departamento de Ecologia e Zoologia CCB, UFSC, Trindade \\ 88040-900 Florianópolis, SC \\ Brasil \\ Fax: +55-48-331-9672 \\ E-mail: dawifi@ ccb.ufsc.br}

Received March 14, 2000 Accepted March 21, 2001

\section{Abstract}

The livers of Geophagus brasiliensis collected from both a nonpolluted site and a polluted site were analyzed for different antioxidant defenses, $\mathrm{O}_{2}$ consumption, thiobarbituric acid-reactive substance (TBARS) levels, and histological damage. Compared to controls $\left(116.6 \pm 26.1 \mathrm{nmol} \mathrm{g}^{-1}\right)$, TBARS levels were enhanced at the polluted site $\left(284.2 \pm 25.6 \mathrm{nmol} \mathrm{g}^{-1}\right)$, as also was oxygen consumption (86.6 \pm 11.3 and $128.5 \pm 9.8 \mu \mathrm{mol} \mathrm{O}_{2} \mathrm{~min}^{-1} \mathrm{~g}^{-1}$, respectively). With respect to enzymatic antioxidants, increased catalase activities $(8.7 \pm 1.3$ and $29.2 \pm 2.4 \mathrm{mmol} \mathrm{min}^{-1} \mathrm{~g}^{-1}$, respectively), unchanged superoxide dismutase activities (767.2 \pm 113.3 and $563.3 \pm 70.2 \mathrm{U} \mathrm{g}^{-1}$, respectively), and diminished glutathione S-transferase activities $(29.0 \pm 3.2$ and $14.9 \pm 3.2 \mu \mathrm{mol} \mathrm{min} \mathrm{m}^{-1} \mathrm{~g}^{-1}$, respectively) were detected. Reduced glutathione ( $1.91 \pm 0.17$ and $1.37 \pm 0.25 \mathrm{mM}$, respectively), oxidized glutathione $(1.50 \pm 0.20$ and $0.73 \pm 0.17 \mathrm{mM}$, respectively), and total glutathione $(3.40 \pm 0.26$ and $2.07 \pm 0.27 \mathrm{mM}$, respectively) concentrations were also below control values at the polluted site. Nevertheless, the observed ethoxyresorufin- $O$-deethylase activities $(1.34 \pm 0.11$ and $16.7 \pm 0.21 \mathrm{pmol} \mathrm{min}^{-1} \mathrm{mg}^{-1}$, respectively) showed enhanced values at the polluted site. The main histological damage observed in the hepatocytes from fish collected at the polluted site was characterized by heavy lipid infiltration. Fish collected at the end of spring showed higher $\mathrm{O}_{2}$ consumption, higher superoxide dismutase and glutathione S-transferase activities, and higher total and oxidized glutathione concentrations compared to the beginning of autumn. No seasonal changes were observed in catalase activities, glutathione or TBARS levels. Fish chronically exposed to relatively high pollution levels seem to be unable to set up adequate antioxidant defenses, probably due to severe injury to their hepatocytes. The higher antioxidant defenses found at the end of spring are probably related to the enhanced activities during high temperature periods in thermoconforming organisms.
Key words

- Oxyradicals

- Antioxidant defenses

- Fish

- Acará

- Season

- Pollution

- Adaptation 


\section{Introduction}

Qualitative data related to the evaluation of enzymatic antioxidants in fish such as superoxide dismutase (SOD) and catalase show that they are structurally and functionally very similar to those of mammals $(1,2)$. Nevertheless, fish enzyme specific activities are quantitatively lower than those of mammals (1-4). Industrial and agricultural activities depend on the production and utilization of a variety of chemical and physical agents that continuously damage the natural environment. Much evidence indicates that xenobiotics can generate reactive oxygen species, including superoxide anion $\left(\mathrm{O}_{2}{ }^{\bullet-}\right)$, hydrogen peroxide $\left(\mathrm{H}_{2} \mathrm{O}_{2}\right)$, hydroxyl radical $\left({ }^{\circ} \mathrm{OH}\right)$, and singlet oxygen $\left(\mathrm{O}_{2}{ }^{1}\right)$, which in turn are responsible for cell and tissue damage associated with different pathologic processes, including mutagenesis and carcinogenesis (5). Recently, oxidative stress and some parameters of fish antioxidant defenses and biotransformation enzymes (i.e., cytochrome P-450 1A1 and glutathione S-transferase, GST) of fish and molluscs have been used as biomarkers of water pollution (6-11). Although the seasonal interference with the antioxidant defense system has not been well established in these organisms, the data available in the literature (12-14) suggest a general antioxidant defense enhancement during spring and summer when compared to low temperature periods. Since most rivers are a sink of numerous spills, urban residues, pesticides and trace metals, the present study was carried out to verify the effect of seasonality and pollution on the antioxidant defense system and the biotransformation system of the acará, Geophagus brasiliensis, caught at a polluted site (Benedito River) compared to fish caught at a non-polluted site (Ratones), southern Brazil.

\section{Material and Methods}

Adult male specimens weighing 15 to 40
$\mathrm{g}(\mathrm{N}=28)$ were collected from a non-polluted pond at Ratones, a private fish farm located far away from the influence of urban areas, on Santa Catarina Island (27० 34' 14"$27^{\circ} 35^{\prime} 31^{\prime \prime} \mathrm{S} ; 48^{\circ} 30^{\prime} 07^{\prime \prime}-48^{\circ} 31^{\prime} 33^{\prime \prime} \mathrm{W}$ ), and the same number $(\mathrm{N}=28)$ of specimens was collected from a polluted area (Benedito River), located near the town of Indaial, in the northern part of the State of Santa Catarina, southern Brazil. For the investigation of seasonal variations, fish $(\mathrm{N}=40)$ were collected only at the non-polluted site Ratones. Twenty adult males were sampled during the month of November, corresponding to the end of spring in the southern hemisphere, and 20 specimens were sampled during the month of April, corresponding to the beginning of autumn.

After biometry, the livers of the animals were carefully excised and rapidly weighed, and tissue oxygen consumption was measured in a thermostated $\left(25 \pm 1^{\circ} \mathrm{C}\right)$ Tucker chamber containing a Clark electrode, where minute tissue slices were kept in Ringer solution for teleosts, containing $15 \mathrm{mM}$ glucose (final concentration). The homogenates were obtained in $20 \mathrm{mM}$ Na-phosphate buffer, $\mathrm{pH} 7.4$, containing $0.1 \%$ Triton X-100 and $0.15 \mathrm{M}$ sodium chloride. Homogeneizations were carried out at $4^{\circ} \mathrm{C}$ using 15 strokes in a Potter-Elvehjem homogenizer, followed by centrifugation at $5000 \mathrm{~g}$ for $10 \mathrm{~min}$ at $4{ }^{\circ} \mathrm{C}$. The supernatants were used for evaluation of antioxidants and thiobarbituric acidreactive substance (TBARS) contents. Aliquots of the corresponding extracts were stored in liquid nitrogen $\left(-170^{\circ} \mathrm{C}\right)$ and examined separately for each enzyme.

The different parameters were analyzed spectrophotometrically according to the following procedures: SOD at $550 \mathrm{~nm}$ by the reduction of cytochrome $c$ promoted by the superoxide anion generated by the xanthine/ xanthine oxidase system (15), and catalase at $240 \mathrm{~nm}$ by the decay of hydrogen peroxide levels (16). GST was measured at $340 \mathrm{~nm}$ using 1-chloro-2,4-dinitrobenzene as sub- 
strate (17); reduced glutathione was determined by the DTNB [5,5'-dithio-bis(2nitrobenzoic acid)] method at $412 \mathrm{~nm}$ (18); total glutathione and oxidized glutathione were determined by the enzymatic method at $412 \mathrm{~nm}$ (19); lipid oxidation was measured at $535 \mathrm{~nm}$ by the TBARS method $(20,21)$.

Ethoxyresorufin- $O$-deethylase (EROD) activity, which is associated with the expression of cytochrome P-450 1A, was estimated by direct fluorimetric detection of the 7 hydroxyresorufin metabolite, essentially as reported by Prough et al. (22). Microsomes were prepared by the calcium aggregation method and differential centrifugation (23), and protein content was determined by the method of Lowry et al. (24).

Histopathological analysis was carried out by light microscopy on liver slices fixed in $10 \%$ buffered Bouin and stained with hematoxylin-eosin.

Statistical analysis was performed using the Student $t$-test with a confidence interval of $5 \%(\mathrm{P}<0.05)$.

\section{Results and Discussion}

\section{Effect of pollution}

Oxygen consumption and TBARS levels were significantly increased at the polluted site compared to control (Figure 1A,B). An increase in metabolic rate is typically associated with acute and chronic stress in fish (25), and a TBARS increase in liver of fish chronically exposed to pollutants has also been well documented in the literature (e.g., 7,26 ). The only antioxidant defense enhancement observed in fish from the polluted area was the increase in catalase activity (Figure 1C), the same response as that found in the mullet (27), but opposite to that found in the Nile tilapia (28). On the other hand, liver SOD activity of fish caught in the polluted area exhibited lower values than fish collected at the reference site (Figure 1D). A similar pattern was observed for GST activ- ity and reduced glutathione concentrations, with both parameters being significantly decreased in relation to controls (Figure 2A,B). The induction of liver catalase activity in the acará exposed to pollutants may reflect an increase in endogenous hydrogen peroxide levels, despite the fact that the tendency towards diminished SOD activity would yield less hydrogen peroxide. Since hydrogen peroxide elimination through the gills occurs in the acará (data not shown), probably consisting of a widespread mechanism in waterbreathing organisms (29), and considering that this elimination accompanies the increase in oxygen consumption and therefore the oxyradical generation, the interpretation of this increase in liver catalase activity becomes rather difficult. Nevertheless, although reduced glutathione peroxidase $(25,30)$ and glutathione reductase (25) activities were found in fish exposed to environmental pollution, both enzymes in general showed induced activities in the liver $(7,28,31)$. These
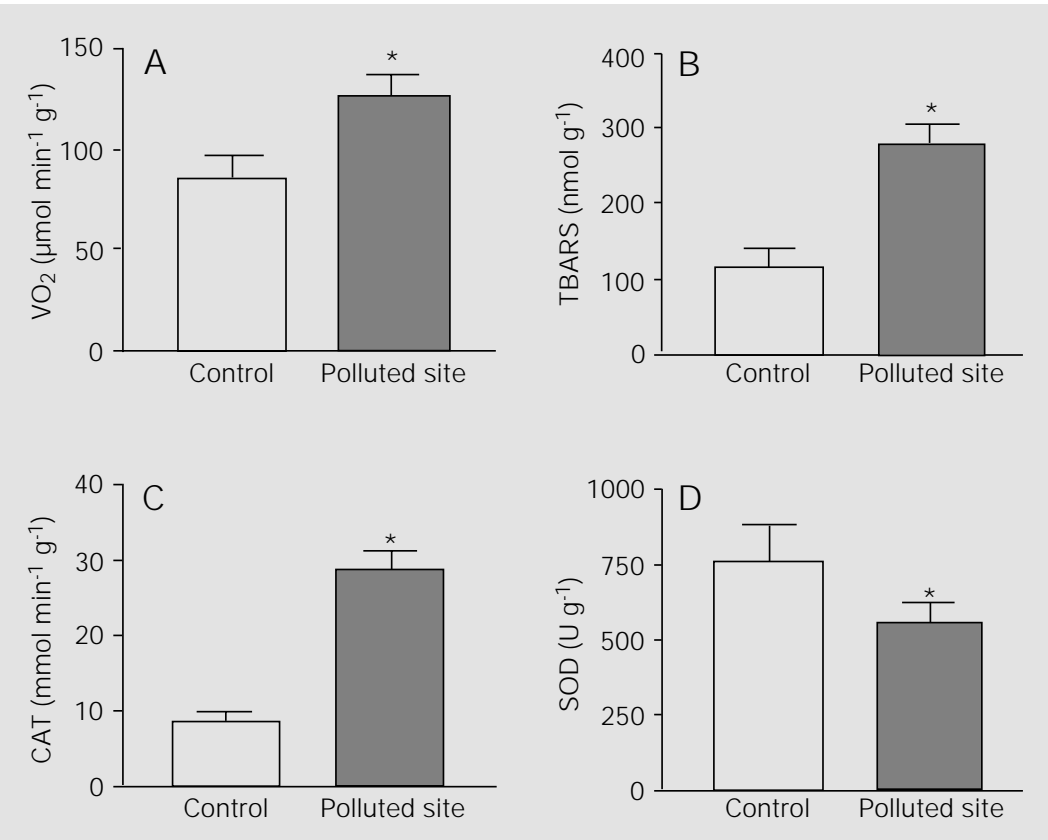

Figure 1. Comparison between different parameters measured in the liver of Geophagus brasiliensis collected at the polluted and at a reference site (control). A, Oxygen consumption $\left(\mathrm{VO}_{2}, \mu \mathrm{mol} \mathrm{min}{ }^{-1} \mathrm{~g}^{-1}\right)$; $\mathrm{B}$, cellular damage (TBARS, $\left.\mathrm{nmol} \mathrm{g}^{-1}\right)$; $\mathrm{C}$, catalase activities (CAT, $\mathrm{mmol} \mathrm{min}^{-1} \mathrm{~g}^{-1}$ ); $\mathrm{D}$, superoxide dismutase activities (SOD, $\left.\mathrm{U} \mathrm{g}{ }^{-1}\right)$. $* \mathrm{P}<0.05$ compared to control (Student t-test). 
findings emphasize the need for healthy hepatocytes to detoxify peroxides, irrespective of the induction of catalase and/or glutathione peroxidase, and the importance of keeping constitutively high levels of reduced glutathione.

The concentrations of total and reduced glutathione found in the liver of Geophagus were similar to those usually found in other fish species exposed to pollutants $(26-28,32)$. Reduced glutathione and TBARS/malondialdehyde concentrations in the liver of acará showed an inverse correlation, and the same relationship was found in other fish (32).

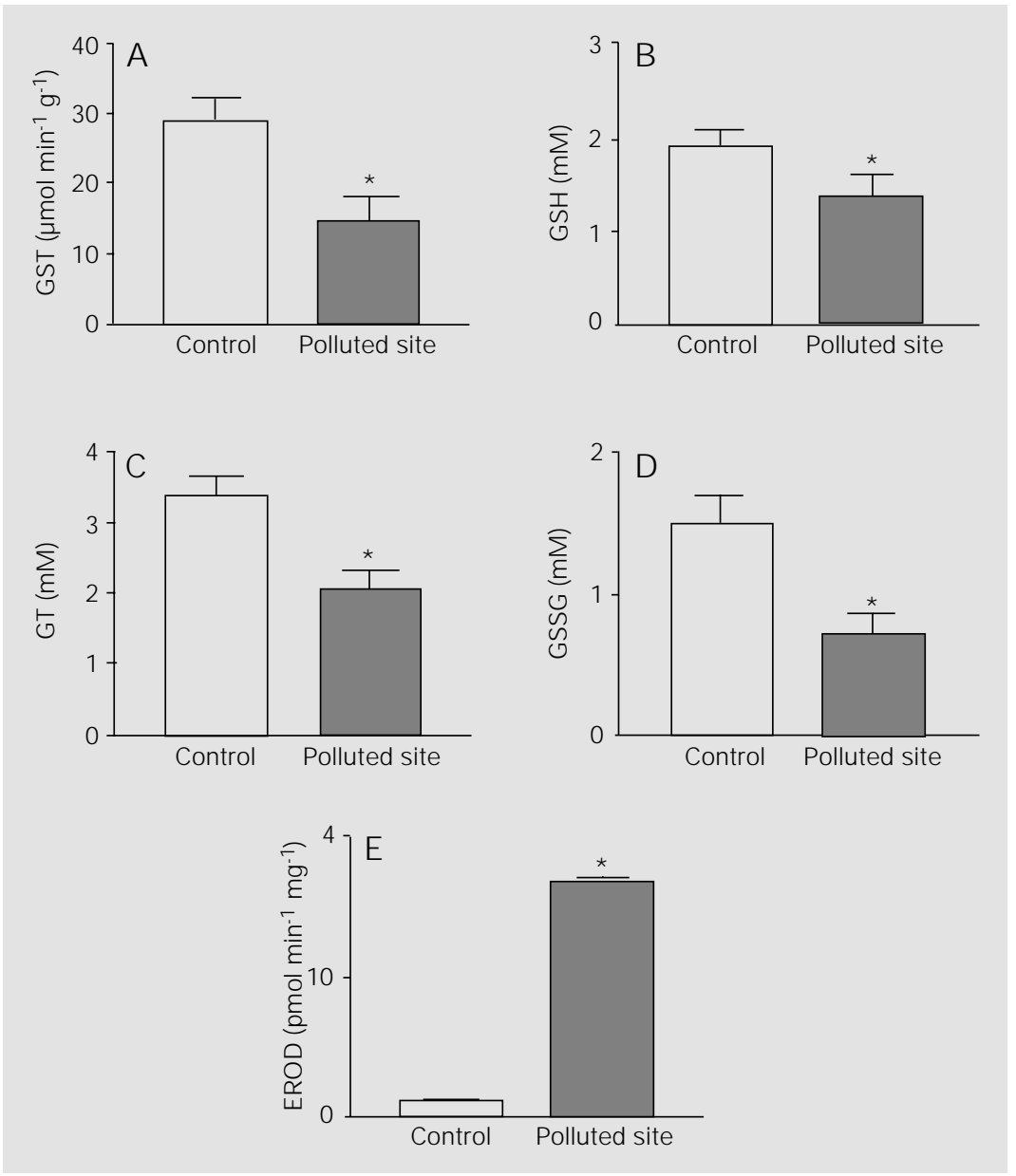

Figure 2. Comparison between different parameters measured in the liver of Geophagus brasiliensis collected at a reference site (control) and at a polluted site. A, Glutathione Stransferase activities (GST, $\left.\mu \mathrm{mol} \mathrm{min}^{-1} \mathrm{~g}^{-1}\right) ; \mathrm{B}$, reduced glutathione (GSH, $\mathrm{mM}$ ); C, total glutathione (GT, $\mathrm{mM}$ ); D, oxidized glutathione (GSSG, $\mathrm{mM}$ ); $\mathrm{E}$, ethoxyresorufin-O-deethylase activities (EROD, pmol min-1 $\mathrm{mg}^{-1}$ ). $* \mathrm{P}<0.05$ compared to control (Student t-test).
Acute and subchronic exposure to pollutants seems to increase reduced glutathione contents in fish cells $(26,32-34)$ while fish submitted to heavy and extensive chronic exposure seem to be unable to maintain high constitutive glutathione and total glutathione levels $(11,28$; Wilhelm Filho D, Torres MA, Testa CP and Tribess TB, unpublished results; present study). The decrease observed both in reduced and oxidized glutathione concentrations may be attributable to the decrease in total glutathione.

The apparent absence of SOD and GST induction and the low total glutathione levels (Figures 1D and 2A,C), together with the histological damage, may be attributable to the extension of the lesions found in the liver. In this regard, fish collected at the polluted site showed drastic lipid infiltration characterized by foamy structures in the adipocytes (Figure 3B). Nevertheless, no significant differences in micronucleus incidence were detected in Geophagus sampled at the polluted site in comparison to fish sampled in pristine upstream waters of the same river (35). Although some studies have shown induction of $\operatorname{SOD}(27,28)$ and other antioxidants (27) or biotransformation enzymes $(27,28,31)$ under pollution exposure, unaltered or lowered SOD activities have been also found in other fish species $(7,32)$. GST, together with EROD activity, is usually enhanced after exposure to different types of organic pollutants, both in laboratory studies (e.g., 31,34) and in field studies $(27,31)$. They represent a complex system related to xenobiotic biotransformation (phase I) and conjugation and excretion (phase II), consisting of prospective biochemical markers of environmental contamination by organic compounds such as polycyclic aromatic hydrocarbons and polychlorinated biphenyls (36). Surprisingly, EROD activities showed enhanced values at the polluted site $\left(16.7 \pm 0.21 \mathrm{pmol} \mathrm{min}^{-1} \mathrm{mg}^{-1}\right)$ in comparison to controls $(1.34 \pm 0.11 \mathrm{pmol}$ $\mathrm{min}^{-1} \mathrm{mg}^{-1}$ ), while GST activities were lower 
at the polluted site $\left(14.9 \pm 3.2 \mu \mathrm{mol} \mathrm{min} \mathrm{m}^{-1} \mathrm{~g}^{-1}\right)$ in comparison with the control group $(29.0 \pm$ $\left.3.2 \mu \mathrm{mol} \mathrm{min}{ }^{-1} \mathrm{~g}^{-1}\right)$. This suggests an uncoupled process between the phase I and phase II systems, reinforcing the above inference that fish from the polluted site are unable to set up adequate compensation, because the reactive metabolites generated in phase I will not be properly neutralized in phase II. If fish are not able to make further investments due to hepatic failure in such a system, at least considering the decreased GST activities, they probably also cannot adequately cope with an oxidative challenge. The Benedito River is characterized as a sink of a variety of pollutants over many years, and receives a complex mixture of domestic residues, different industrial effluents, and agricultural chemicals (37). Therefore, the fish sampled in this freshwater system were considered to have been long-term exposed to a heavily polluted environment. In animals experiencing intense chronic stress the stress response may lose its adaptive value and become dysfunctional (38). The above results suggest that protein synthesis in liver was probably generally affected in fish collected at the polluted site, and the observed lipid accumulation in the hepatocytes (Figure 3B) may be linked to the lack of sufficient protein transport of lipids in plasma (38). Accordingly, the histological damage was already evident when fish were dissected for liver excision. In this regard, some specimens revealed a high degree of organ fragility, and tissues were sometimes disrupted even if carefully manipulated, indicating severe tissue injury. Furthermore, the increase of the somatic index (percent organ weight compared to body weight) of liver from fish collected at the polluted site (2.70 $\pm 0.44 \%$ ) compared to the index of fish collected at the reference site $(1.11 \pm 0.35 \%)$ also confirms histological damage provoked by pollution in fish (38). A study carried out in our laboratory on an estuarine catfish species also chronically exposed to heavy anthropogenic influence revealed similar results (Wilhelm Filho D, Torres MA, Testa CP, Tribess TB, Pedrosa RC and HostimSilva M, unpublished results), also suggesting that highly polluted environments can jeopardize an adequate compensatory response of the liver.

\section{Effect of season}

Healthy fish collected at the non-polluted site during the high temperature period
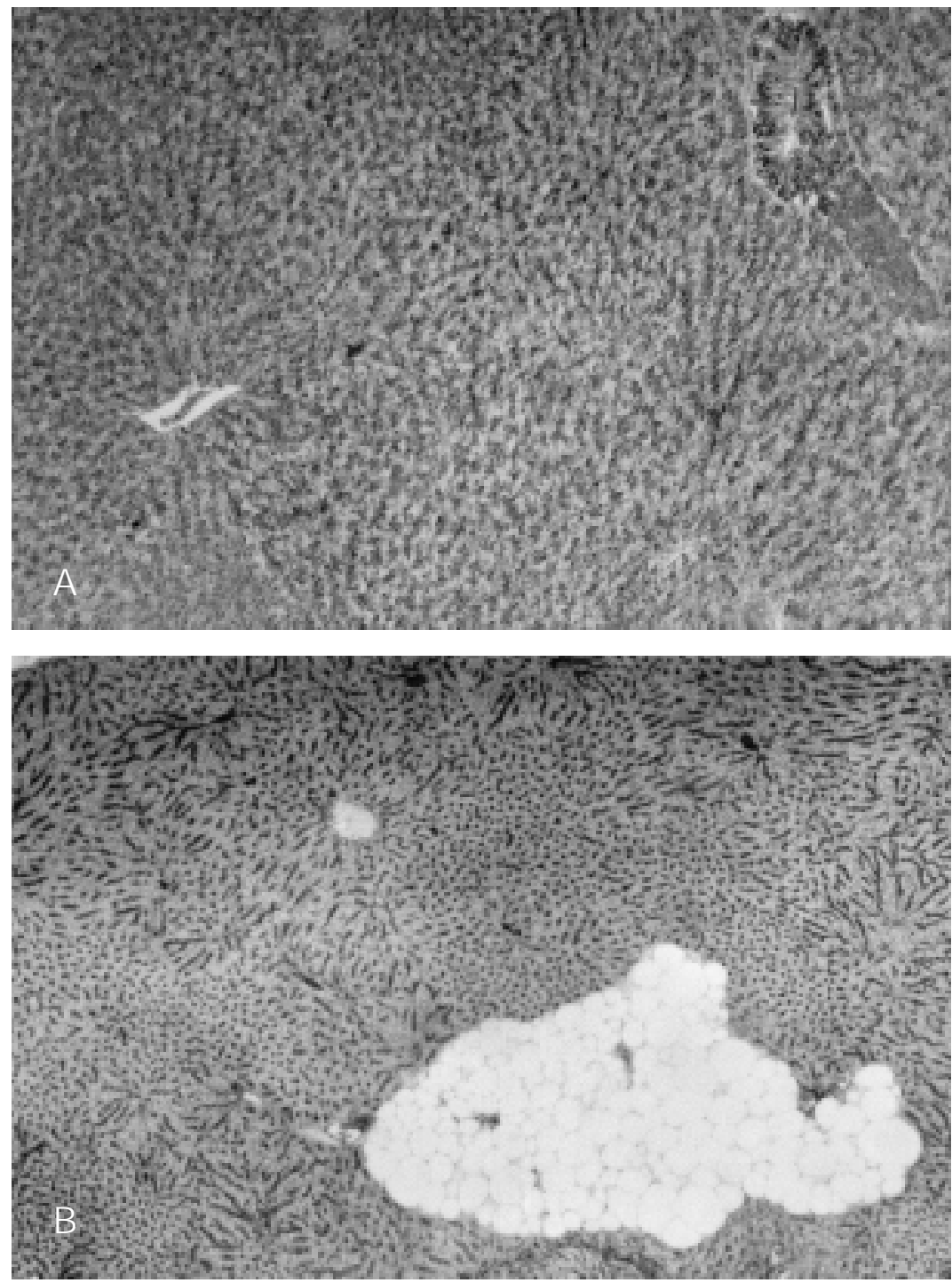

Figure 3. Microscopic view of the liver of Geophagus brasiliensis stained with hematoxylineosin, collected at a reference site ( $A$; magnification, 100X) and the polluted site (Benedito River) (B; magnification, 40X ). Lipid infiltration can be observed in B. 

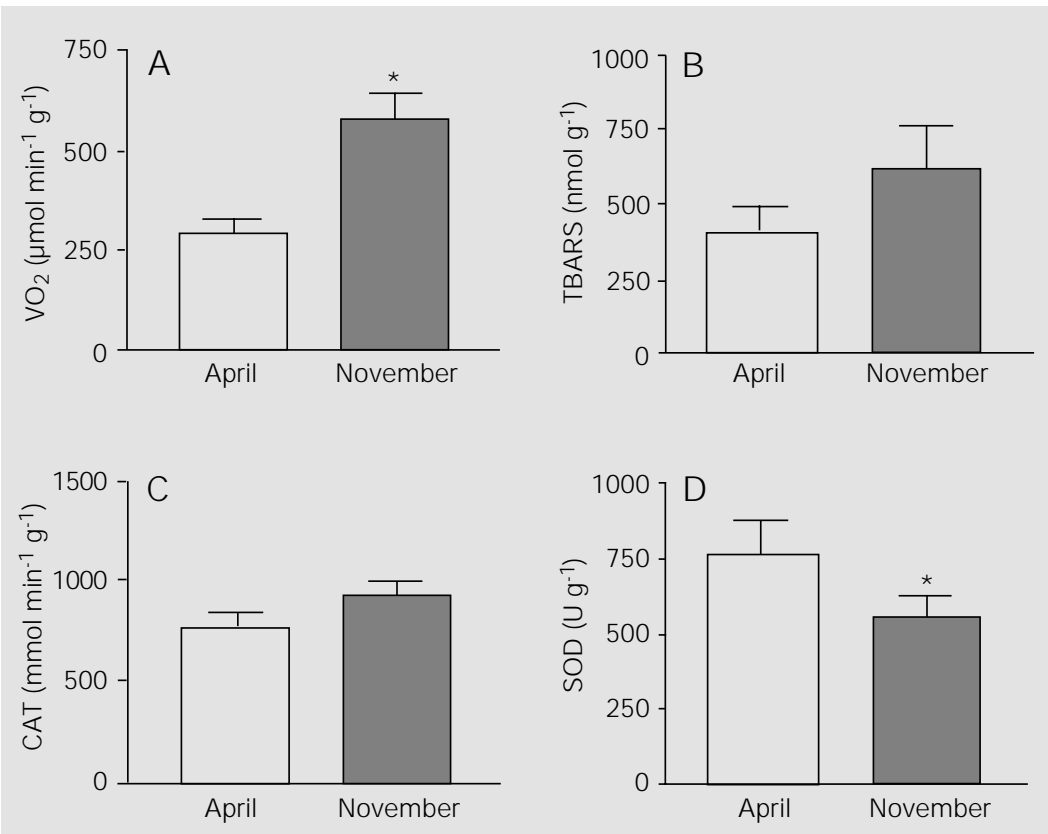

Figure 4. Seasonal pattern of different parameters measured in the liver of Geophagus brasiliensis. A, Oxygen consumption $\left(\mathrm{VO}_{2}, \mu \mathrm{mol} \mathrm{min}{ }^{-1} \mathrm{~g}^{-1}\right)$; $\mathrm{B}$, cellular damage (TBARS, $\mathrm{nmol} / \mathrm{g}$ ); C, catalase activities (CAT, mmol $\mathrm{min}^{-1} \mathrm{~g}^{-1}$ ); $\mathrm{D}$, superoxide dismutase activities (SOD, $\mathrm{U} \mathrm{g}^{-1}$ ). *P<0.05 compared to samples collected in April (Student t-test).
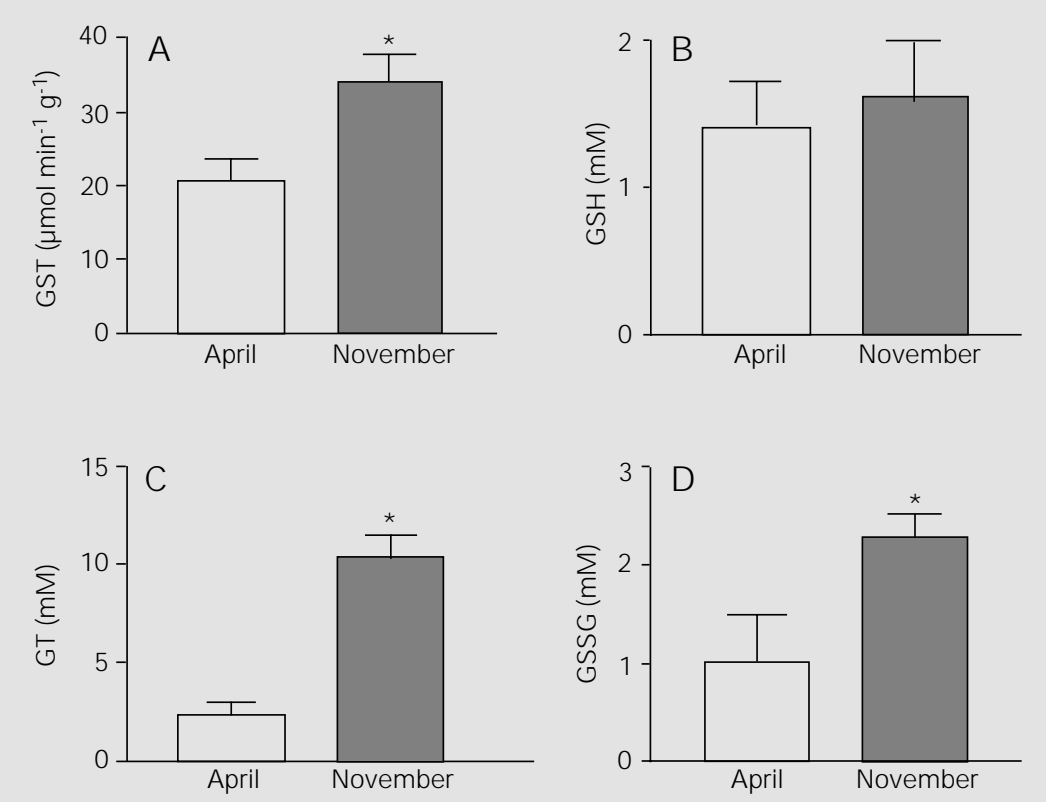

Figure 5. Seasonal pattern of different parameters measured in the liver of Geophagus brasiliensis. A, Glutathione S-transferase activities (GST, $\mu \mathrm{mol} \mathrm{min}^{-1} \mathrm{~g}^{-1}$ ); B, reduced glutathione (GSH, mM); $\mathrm{C}$, total glutathione (GT, mM); $\mathrm{D}$, oxidized glutathione (GSSG, $\mathrm{mM}$ ). $* \mathrm{P}<0.05$ compared to samples collected in April (Student t-test).
(November, spring) showed higher oxygen consumption, higher SOD and GST activity, and also higher total and oxidized glutathione concentrations in the liver (Figures 4D and $5 \mathrm{~A}$ ) compared to fish collected during the month of April (autumn). Although catalase activities and TBARS contents did not show any significant differences, the values of both parameters tended to increase in the warmer period (Figure 4B,C). Similar seasonal patterns, i.e., enhancement of antioxidants coinciding with high water temperatures, were verified in other fish (12-14; Wilhelm Filho D, Fraga CG and Boveris A, unpublished results), and also in a bivalve mollusc (39).

Total and oxidized glutathione were higher during the warm period compared to the cold period (Figure 5C,D). The enhancement of oxidized glutathione levels shown by fish collected during the warm period coincided with the increase in oxygen consumption and might represent a situation of oxidative stress. This increase is probably related to the higher ambient water temperature and therefore to the oxygen consumption and reactive oxygen species generation during the warm period. Seasonal adjustments in the antioxidant defense of thermoconformers like most fish and invertebrates suggest that this mechanism is a common adaptation in thermoconformer vertebrates and invertebrates. In a recent study (40), such a correlation between antioxidant defenses and water temperature was not found in the eelpout Zoarces viviparus. Nevertheless, viviparity implies extensive anabolic investments, and the eelpout seems to be unable to sustain a high antioxidant status from spawning to parturition. With the exception of glutathione reductase, all the other antioxidants and biotransformation enzymes showed decreased activities during this period, the gonadosomatic index was inversely related, and the liver somatic index was directly related to the antioxidants (40).

The seasonal variation observed here in 
phase II conjugation-excretion activities of GST was also observed in a mussel species (39), but contrasts with the seasonal independence of this biomarker in another mussel species (41). Conversely, phase I activities associated with cytochrome P-450 1A displayed enhanced values in estuarine catfish sampled in the winter in comparison with animals sampled during summer (Geremias R, Curi-Pedrosa R, Wilhelm Filho D, Hostim-Silva M, Figna V and Locatelli C, unpublished results). The persistence of a xenobiotic compound depends on many features, including seasonality and reproductive cycle, its chemical properties, specific rates of bioconcentration and biotransformation, and also specific excretory mechanisms (42).

Specific tissues and organs can display different antioxidant defense status (4) depending on the organism and the circumstances involved (habit, habitat, age, thermoregulatory capacity, metabolic rate and nutritional status, among others). These assumptions are determinant if we consider that, even though the different antioxidant defenses are unevenly distributed in tissues and organs in quantitative terms and are located in subcellular compartments, they often act in a concerted way by synergism (5).

In conclusion, among other aspects, the seasonal influences need to be better understood in order to make further inferences regarding antioxidant defenses and biotransformation enzymes, especially in thermoconformers such as most fish and aquatic invertebrates living in non-polluted or polluted environments. Time of exposure and pollution levels seem to determine quantitatively the kind of response regarding biotransformation enzymes and antioxidants in fish, and this response depends therefore on the functional capacity of the organ and tissues involved. The use of biochemical indicators in environmental pollution studies at a lower organizational level such as in the present study is of high toxicological relevance (6), and oxidant-mediated responses are useful indices of environmental quality (25).

\section{References}

1. Wilhelm Filho D (1996). Antioxidant defenses in fish: a comparative approach. Brazilian J ournal of Medical and Biological Research, 29: 1735-1742.

2. Aksnes A \& Njaa LR (1981). Catalase, glutathione peroxidase, and superoxide dismutase in different fish species. Comparative Biochemistry and Physiology, 69B: 893-896.

3. Wilhelm Filho $D \&$ Boveris A (1993). Antioxidant defenses in marine fish. II. Elasmobranchs. Comparative Biochemistry and Physiology, 106C: 415-418.

4. Wilhelm Filho $D$, Giulivi $C \&$ Boveris $A$ (1993). Antioxidant defenses in marine fish. I. Teleosts. Comparative Biochemistry and Physiology, 106C: 409-413.

5. Halliwell B \& Gutteridge J MC (1998). Free Radicals in Biology and Medicine. 3rd edn. Clarendon Press, Oxford.

6. Adams SM, Shepard KL, Greeley J r MS, J imenez BD, Ryon MG, Shugart LR, McCarthy J F \& Hinton DE (1989). The use of bioindicators for assessing the effects of pollutant stress on fish. Marine Environmental Research, 28: 459-464.

7. Karakoc FT, Hewer A, Phillips DH, Gaines AF \& Yuregir G (1997). Biomarkers of marine pollution observed in species of mullet living in two eastern Mediterranean harbours. Biomarkers, 2: 303-309.

8. Malins DC, MCCain BB, Lindhal JT, Meyers MS, Krahn MM, Brown DW, Chan SL \& Roubal WT (1988). Neoplasic and other diseases in fish in relation to toxic chemicals: an overview. Aquatic Toxicology, 11: 43-67.

9. Thurman RG, Kauffman FC \& Baron J (1986). Biotransformation and zonal toxicity. In: Thurman RG, Kauffman FC \& J ungermann K (Editors), Regulation of Hepatic Metabolism. Plenum Press, New York.

10. Di Giulio RT, Washburn PC \& Wenning RJ (1989). Biochemical responses in aquatic animals: a review of determinants of oxidative stress. Environmental Toxicology and Chemistry, 8: 1103-1123.
11. Bagnasco MA, Camoirano A, DeFlora S, Melodia F \& Arillo A (1991). Enhanced liver metabolism of mutagens and carcinogens in fish living in polluted seawater. Mutation Research, 262: 129-137.

12. Härdig J \& Höglund LB (1983). Seasonal and ontogenetic effects on methaemoglobin and reduced glutathione content in the blood of reared baltic salmon. Comparative Biochemistry and Physiology, 75A: 27-34.

13. Gabryelak T, Piatkowska M, Leyko W \& Pérès $G$ (1983). Seasonal variations in the activities of peroxide metabolism enzymes in erythrocytes of freshwater fish species. Comparative Biochemistry and Physiology, 75C: 383-385.

14. Palace UP \& Klaverkamp J F (1993). Variation of hepatic enzymes in three species of freshwater fish from precambrian shield lakes and the effect of cadmium exposure. Comparative Biochemistry and Physiology, 104C: S147-S154.

15. Flohé $L \&$ Ötting $F$ (1984). Superoxide 
dismutase assays. Methods in Enzymology, 105: 93-104.

16. Aebi $\mathrm{H}$ (1984). Catalase in vitro. Methods in Enzymology, 105: 121-126.

17. Habig WH, Pabst MJ \&J acoby WB (1976). Glutathione-S-transferases: the first enzymatic step in mercapturic acid formation. J ournal of Biological Chemistry, 249: 7130-7139.

18. Beutler E, Duron O \& Kelly BM (1963). Improved method for the determination of blood glutathione. J ournal of Laboratory and Clinical Medicine, 61: 882-890.

19. Tietze $F$ (1969). Enzymatic method for quantitative determination of nanogram amounts of total and oxidized glutathione. Analytical Biochemistry, 27: 502-522.

20. Bird RP \& Draper AH (1984). Comparative studies on different methods of malondialdehyde determination. Methods in Enzymology, 90: 105-110.

21. Ohkawa H (1979). Assay for lipid peroxides in animal tissues by thiobarbituric acid reaction. Analytical Biochemistry, 95: 351-358.

22. Prough RA, Burke MD \& M ayer RT (1978). Direct fluorimetric methods for measuring mixed-function oxidase activity. Methods in Enzymology, 52: 372-377.

23. Schenkman J B \& Cinti DL (1972). Preparation of microsome with calcium. In: Fleischer S \& Packer L (Editors), Methods in Enzymology. Academic Press, New York.

24. Lowry $\mathrm{OH}$, Rosebrough NJ, Farr AL \& Randall RJ (1951). Protein measurement with the Folin phenol reagent. J ournal of Biological Chemistry, 193: 265-275.

25. DiGiulio RT, Benson WH, Sanders BM \& Van Veld PA (1995). Biochemical mechanisms: metabolism, adaptation, and toxicity. In: Rand GM (Editor), Fundamentals of Aquatic Toxicology: Effects, Environmental Fate, and Risk Assessment. Taylor \& Francis, London.

26. Thomas $P \&$ Wofford HW (1984). Effects of metals and organic compounds on he- patic glutathione, cysteine, and acidsoluble thiol levels in mullet (Mugil cephalus L.). Toxicology and Applied Pharmacology, 76: 172-182.

27. Rodríguez-Ariza A, Peinado J , Pueyo C \& López-BareaJ (1993). Biochemical indicators of oxidative stress in fish from polluted litoral areas. Canadian J ournal of Fisheries and Aquatic Sciences, 50: 25682573.

28. Bainy $A C D$, Saito $E$, Carvalho PSM \& J unqueira VBC (1996). Oxidative stress in gill, erythrocytes, liver and kidney of Nile tilapia (Oreochromis niloticus) from a polluted site. Aquatic Toxicology, 34: 151162.

29. Wilhelm Filho $D$, Bredeston LM, Bermudez MN \& Boveris A (1999). Hydrogen peroxide diffusion in fish gills. In: Val AL \& Almeida e Val VMF (Editors), Biology of Tropical Fishes. INPA, Manaus, AM, Brazil.

30. Lenártová $\mathrm{V}$, Holovská $\mathrm{K}$, Pedrajas J R, Martínez-Lara E, Peinado J , López-Barea J , Rosival I \& Kosuth P (1997). Antioxidant and detoxifying fish enzymes as biomarkers of river pollution. Biomarkers, 2: 247252.

31. Machala M, Petrivalsky M, Nezveda K, Ulrich R, Dusek L, Piaka V \& Svobodová Z (1997). Responses of carp hepatopancreatic 7-ethoxyresorufin-O-deethylase and glutathione-dependent enzymes to organic pollutants - A field study. Environmental Toxicology and Chemistry, 16: 1410-1416.

32. Wilhelm Filho $D$, Baptista IE, Soares CHL $\&$ Pedrosa RC (1997). The effect of pulp mill effluent on two fish species. Proceedings of the Fifth Brazilian Symposium on the Chemistry of Lignins and other Wood Components, Curitiba, PR, Brazil, August 31-September 5, 612-619.

33. Wofford HW \& Thomas P (1988). Effect of xenobiotics on peroxidation of hepatic microsomal lipids from striped mullet (Mugil cephalus) and atlantic croaker (Mi- cropogonias undulatus). Marine Environmental Research, 24: 285-289.

34. Petrivalsky M, Machala $M$, Nezveda $K$, Piaka V, Svobodová Z \& Drabek P (1997). Glutathione-dependent detoxifying enzymes in rainbow trout liver: search for specific biochemical markers of chemical stress. Environmental Toxicology and Chemistry, 16: 1419-1421.

35. Bueno AMS (2000). Biomonitoramento citogenético in situ: um instrumento indicador de genotoxidade ambiental. Biotemas, 13: 137-158.

36. Goksøyr A \& Förlin L (1992). The cytochrome P-450 system in fish, aquatic toxicology and environmental monitoring. Aquatic Toxicology, 22: 287-312.

37. Bueno AMS (1997). Utilização de roedores silvestres no biomonitoramento citogenético in situ. Doctoral thesis, Instituto de Biociências, Universidade de São Paulo, São Paulo, SP, Brazil.

38. Bonga SEW (1997). The stress response in fish. Physiological Reviews, 77: 591625.

39. Wilhelm Filho D, Tribess TM, Gáspari $C$, Claudio FD, Magalhães ARM \& Torres MA (2001). Seasonal changes in the antioxidant defenses of the mussel Perna perna. Aquaculture (in press).

40. Ronisz D, Larsson DG \& Förlin L (1999). Seasonal variations in the activities of selected hepatic biotransformation and antioxidant enzymes in eelpout (Zoarces viviparus). Comparative Biochemistry and Physiology, 124C: 271-279.

41. Sheehan D \& Power A (1999). Effects of seasonality on xenobiotic and antioxidant defense mechanisms of bivalve mollusc. Comparative Biochemistry and Physiology, 123C: 193-199.

42. Livingstone DR (1998). The fate of organic xenobiotics in aquatic ecosystems: quantitative and qualitative differences in biotransformation by invertebrates and fish. Comparative Biochemistry and Physiology, 120A: 43-49. 